\title{
STABILITY AND MAGNETIC PROPERTIES OF $\mathrm{Co}_{2} \mathrm{O}_{m}$ $(m=1, \ldots, 7)$ CLUSTERS
}

\author{
J. Tamulienė ${ }^{\mathrm{a}}$, R. Vaišnoras ${ }^{\mathrm{b}}$, G. Badenes $^{\mathrm{c}}$, and L.M. Balevičius ${ }^{\mathrm{d}}$ \\ ${ }^{a}$ Vilnius University Institute of Theoretical Physics and Astronomy, A. Goštauto 12, LT-01108 Vilnius, Lithuania \\ E-mail: gicevic@itpa.lt \\ ${ }^{\mathrm{b}}$ Vilnius Pedagogical University, Studentu 39, LT-08016 Vilnius, Lithuania \\ ${ }^{c}$ The Institute of Photonic Sciences, Av. del Canal Olimpic s/n, 08860 Castelldefels (Barcelona), Spain \\ ${ }^{\mathrm{d}}$ Faculty of Physics of Vilnius University, Saulètekio 9, LT-10222 Vilnius, Lithuania
}

Received 8 December 2008; revised 28 January 2009; accepted 18 June 2009

\begin{abstract}
In the present work theoretical investigations of $\mathrm{Co}_{2} \mathrm{O}_{m}(m=1, \ldots, 7)$ by applying density functional approach are performed. Calculations reveal that the stability of these compounds increases when the number of $\mathrm{O}$ atoms increases. The increase of the number of the oxygen atoms leads to the elongation of the $\mathrm{Co}-\mathrm{Co}$ bond length. We obtain that the most stable nanoparticle (NP) is $\mathrm{Co}_{2} \mathrm{O}_{6}$. Investigation of magnetization indicates that the NP with high symmetry is demonstrating the paramagnetic features. Calculation results show that only $\mathrm{Co}_{2} \mathrm{O}_{3}$ and $\mathrm{Co}_{2} \mathrm{O}_{4}$ display paramagnetic properties while other investigated NPs $\left(\mathrm{Co}_{2} \mathrm{O}, \mathrm{Co}_{2} \mathrm{O}_{2}\right.$, and $\left.\mathrm{Co}_{2} \mathrm{O}_{6}\right)$ exhibit diamagnetic properties.
\end{abstract}

Keywords: nanoparticles, magnetizability, stability

PACS: 31.15.Ar, 31.15.Ew, 33.15.-e

\section{Introduction}

Properties of nanoparticles (NPs) depend on their size. Magnetic cobalt NPs become very important for their applications in magnetic storage technology. The fast read-write processes in recording nanophotonic devices favour smaller size magnetic NPs, where reduction of magnetic coercivity is expected. However, the stability of NPs is an important factor. Usually a metallic NP easily oxidizes in air and cobalt NPs could loose their magnetic properties. At present NPs and their magnetic properties are the focus of many studies. It is established that for magnetic NPs the surface spins compete with the core spins, resulting in the unusual magnetic properties with a multiple assortment of technological applications which include the biomedical and hard-drive densifying technologies. In this content, the Co NPs are studied very intensively. The application of these particles is ranging from ultrahigh density recording media to medicine and, in addition, they are a traditional precursor of anode materials in Li-ion rechargeable batteries and an effective catalyst in the reduction of $\mathrm{SO}_{2}$ by $\mathrm{Co}$ and $\mathrm{NO}$ by methane [1].

Extensive studies on ferromagnetic bulk materials and thin films have highlighted the magnetic anisotropy energy dependence on crystal symmetry and atomic composition [2]. Even the structural parameters such as the shape of the particles or the interatomic distances are affected by these processes. It has been found that the magnetic anisotropy energy is dependent on singleatom coordination changes. These results confirm the theoretical predictions and are of fundamental value in understanding how the magnetic anisotropy develops in finite-sized magnetic particles [3]. Besides this size effect, the NP behaviour is influenced by the proximity of neighbouring particles, i.e. dipolar interparticle interactions lead to the appearance of collective behaviour [4]. On the other hand, the structure effects a high chemical stability of NPs even if they are in contact with the ambient, in particular with oxygen.

Pure CoO NPs in the 4.5-18 nm range have been prepared by the decomposition of Co(II) cupferronate [5]. These particles exhibit a superparamagnetic behaviour at room temperature, and a large orbital contribution to the magnetic moment at low temperatures has been observed. The core-shell NPs (Co-CoO) are examined and it is established that the magnetic properties of these particles strongly depend on the plane coverage. The reported results demonstrate the essential role played by shells in stabilizing the magnetism of Co-CoO NPs. Some reports on the preparation and properties of pure 
$\mathrm{CoO}$ in bulk describe the difficulties to obtain the materials in pure form by simple methods [6]. The particles are often being contaminated with $\mathrm{Co}_{3} \mathrm{O}_{4}$ or Co metal. The greater stability of $\mathrm{Co}_{3} \mathrm{O}_{4}$ than $\mathrm{CoO}$ is also established. However, the reports concerning the other $\mathrm{Co}_{n} \mathrm{O}_{m}$ particle properties are not known and there is no clear indication on structure and stability of these Co NPs. Thus, the aim of our investigations is to shed some light on the stability and magnetic properties of the $\mathrm{Co}_{n} \mathrm{O}_{m}$ particles.

\section{Description of method}

The structural origin of clusters has been studied by using the generalized gradient approximation for the exchange-correlation potential in the density functional theory (DFT) as described by Becke's three-parameter hybrid functional, using the non-local correlation provided by Lee, Yang, and Parr. The DFT method is commonly referred to as B3LYP [7], - a representative standard DFT method. The 6-31G basis set has been used as well [8]. The basis set was chosen keeping in mind relatively minimum computational costs. The structures of the investigated NPs have been optimized globally without any symmetry constraint and by starting from various initial geometry constructed according to certain symmetry in order to determine the lowest energy structures of each cluster. We have examined almost all candidate configurations with different symmetry for cluster $\mathrm{Co}_{2} \mathrm{O}_{m}(m=1, \ldots, 7)$. The GAMESS and Gaussian program suites were used for all simulations here $[9,10]$.

Isotropic magnetizabilities of the most stable clusters were calculated by adopting the quantum mechanical response theory and London atomic orbital to ensure gauge-origin independent results and fast basis set convergence by using Dalton program [11]. The approach used allows us to calculate accurate magnetizabilities even for quite large molecules at a moderate cost of computer time. In this case the B3LYP method with Altrichs-pVDZ basis set was used [12]. This basis set has been obtained by optimizing the exponents and contraction coefficients in ground state Restricted Open Hartree-Fock (ROHF) calculations and there are in total 241 contracted functions. It is shown that the isotropic magnetizability and its anisotropy are remarkably constant with respect to the basis set and close to experiment, too [13]. So, the obtained performances allow us to foresee how magnetic properties of the particles depend on their structures.

\section{Investigation results}

Stability of small Co NPs is not very high [14]. On the basis of our previous investigation it is speculated that these NPs are non-rigid structures. It implies that the geometrical structure of these particles could change very quickly due to the tunnelling effect. Hence, we are trying to answer the question what and how can change the stability, structure, and, as a consequence, the properties of small Co NPs. So, $\mathrm{Co}_{2} \mathrm{O}_{m}$ $(m=1, \ldots, 6)$ derivatives were investigated to find the most stable ones and to establish the number of $\mathrm{O}$ atoms that Co atoms may accept. On the other hand, the investigations allow us to foresee the condition for the breaking of metal Co-Co bond.

The most stable structures of the $\mathrm{Co}_{2} \mathrm{O}_{m}$ derivatives are presented in Fig. 1.

Firstly, it is necessary to mention that two Co atoms could accept only six oxygen atoms. This structure is the most stable. The following increase of the oxygen number leads to $\mathrm{O}-\mathrm{O}$ bond formation, i. e. new $\mathrm{Co}-\mathrm{O}$ bonds are not created. Generally, the increase of the above number up to 6 leads to higher stability of the above derivatives (Fig. 2).

It is emphasized that a small binding energy decrease (the number of oxygen number is 4 ) is related with the Co atom oxidation state. In the compound $\mathrm{Co}_{2} \mathrm{O}_{m}$ ( $m=1,2,3$ ), the oxidation state of Co is +3 , while from $m=4$ this state is +5 . The appearance of $\mathrm{O}-\mathrm{O}$ bonds lowers the stability of Co NPs.

The HOMO-LUMO gap investigations indicated that the stability increased with increasing the number of $\mathrm{O}$ when the Co oxidation state was 3 (Fig. 3). Alternatively, the HOMO-LUMO gap decreases with the growth of the $\mathrm{O}$ number in the case of $\mathrm{Co}^{+5}$ (when the number of $\mathrm{O}$ changes from 4 to 5 and from 6 to 7). The observations could be related with the $\mathrm{Co}-\mathrm{Co}$ bond dissolving in the $\mathrm{Co}_{2} \mathrm{O}_{5}$ and $\mathrm{Co}_{2} \mathrm{O}_{6}$ compounds as well as with the $\mathrm{O}-\mathrm{O}$ bond presence in the $\mathrm{Co}_{2} \mathrm{O}_{7}$ compound. In summary, the results of the investigation confirm that an $\mathrm{O}$ atom should stabilize Co NPs. However, our study indicates that $\mathrm{Co}_{2} \mathrm{O}_{3}$ is more stable than $\mathrm{Co}_{2} \mathrm{O}_{2}$ (or $\mathrm{CoO}$ ) and $\mathrm{Co}_{2} \mathrm{O}_{6}\left(\right.$ or $\left.\mathrm{CoO}_{3}\right)$ should also be more stable than $\mathrm{CoO}$ derivatives.

The attention was paid to the magnetic properties of these derivatives. Magnetizability (commonly known as susceptibility) was investigated. Let us remember that the increase of the number of oxygen atoms in the compound and the changeability of the oxidation state lead to increase of the Co-Co bond length and weakening of $\mathrm{Co}-\mathrm{Co}$ bonds that is important for the magnetic 


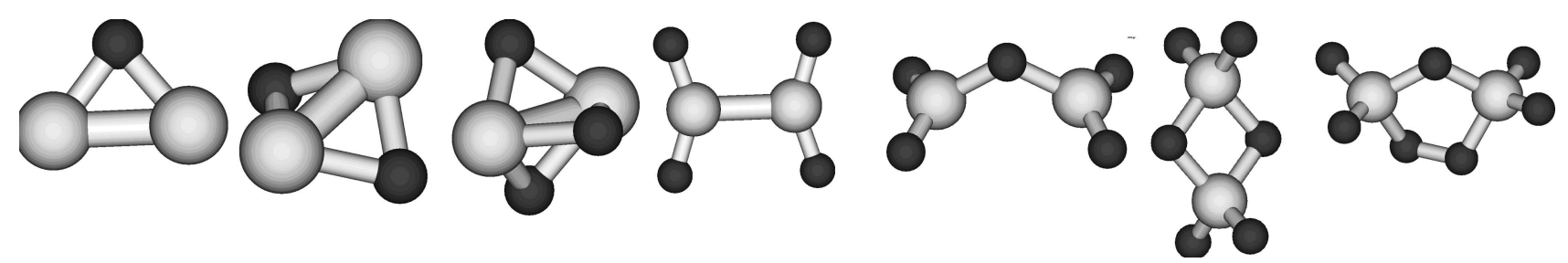

Fig. 1. Views of $\mathrm{Co}_{2} \mathrm{O}_{m}(m=1, \ldots, 7)$.

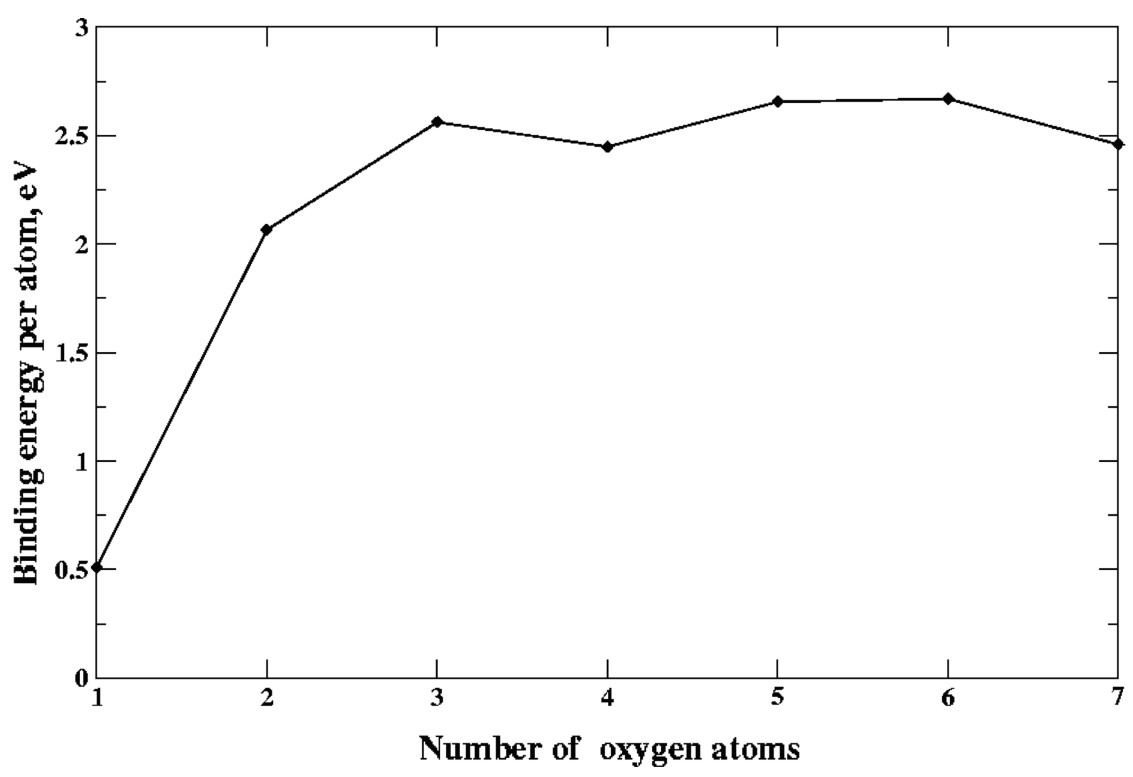

Fig. 2. Dependence of binding energy per atom on the oxygen atom number.

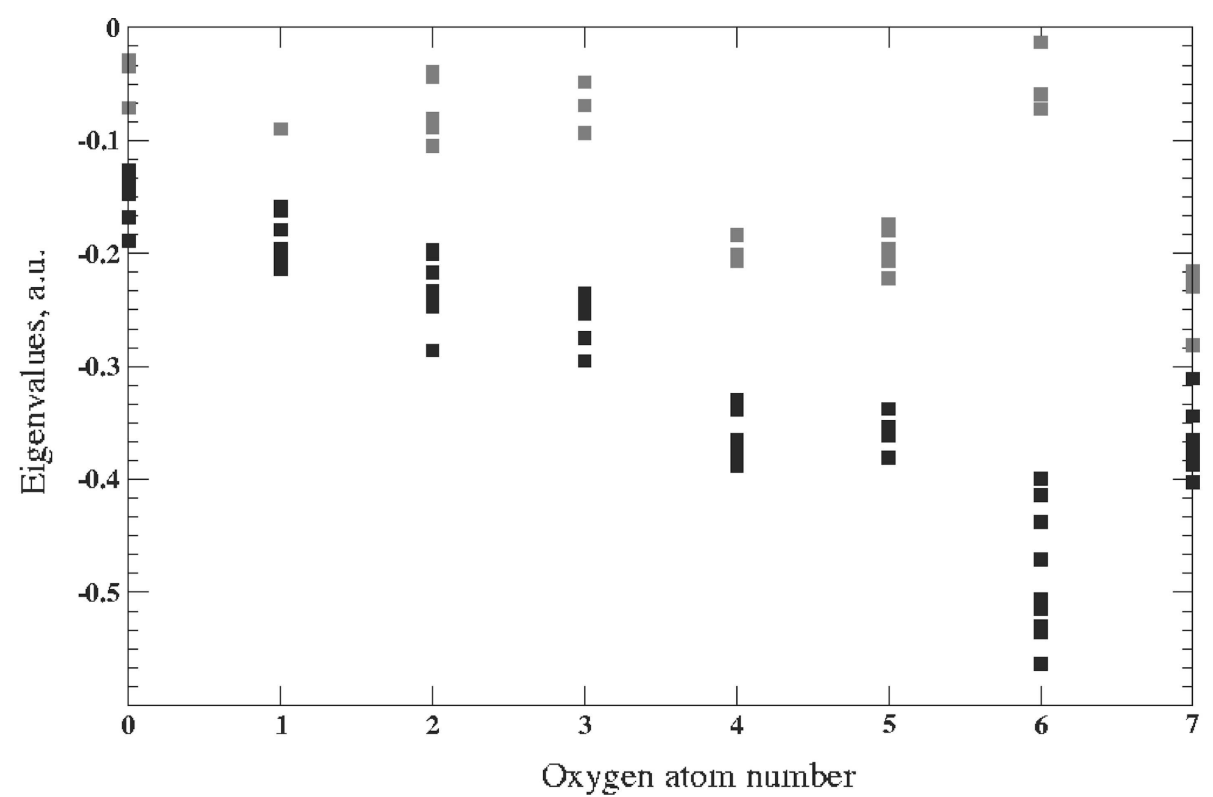

Fig. 3. Schematic orbital diagrams for $\mathrm{Co}_{2} \mathrm{O}_{m}(m=1, \ldots, 7)$ compounds. Black colour represents occupied orbitals while virtual orbitals are marked in grey. 
Table 1. Parameters of the $\mathrm{Co}_{2} \mathrm{O}_{m}(m=1, \ldots, 7)$ particles obtained by B3LYP/6-31G method.

\begin{tabular}{lcccccc}
\hline Compound & $\begin{array}{c}\mathrm{Co}-\mathrm{Co}_{\text {bond length, }} \\
\mathrm{A}\end{array}$ & Bond order & Symmetry & $\begin{array}{c}\text { Magnetizability, } \\
\text { a. u. }\end{array}$ & $\begin{array}{c}\text { Isotropic } g \text { tensor, } \\
\text { a. u. }\end{array}$ & Co oxidation state \\
\hline $\mathrm{Co}_{2} \mathrm{O}$ & 2.11 & 1.53 & $\mathrm{C}_{2 v}$ & -3.26 & -0.36 & III \\
$\mathrm{Co}_{2} \mathrm{O}_{2}$ & 2.11 & 0.84 & $\mathrm{C}_{1 h}$ & -6.07 & -0.24 & III \\
$\mathrm{Co}_{2} \mathrm{O}_{3}$ & 2.24 & 0.24 & $\mathrm{D}_{3 h}$ & 8.99 & -0.58 & III \\
$\mathrm{Co}_{2} \mathrm{O}_{4}$ & 2.29 & 0.68 & $\mathrm{D}_{2 h}$ & 49.05 & -1.17 & $\mathrm{~V}$ \\
$\mathrm{Co}_{2} \mathrm{O}_{5}$ & 2.99 & 0.06 & $\mathrm{C}_{2 v}$ & -1.82 & -0.22 & $\mathrm{~V}$ \\
$\mathrm{Co}_{2} \mathrm{O}_{6}$ & 2.65 & 0.20 & $\mathrm{D}_{2 h}$ & -10.63 & -0.16 & $\mathrm{~V}$ \\
$\mathrm{Co}_{2} \mathrm{O}_{7}$ & 3.00 & 0.20 & $\mathrm{C}_{1}$ & -5.14 & -0.18 & $\mathrm{~V}$ \\
\hline
\end{tabular}

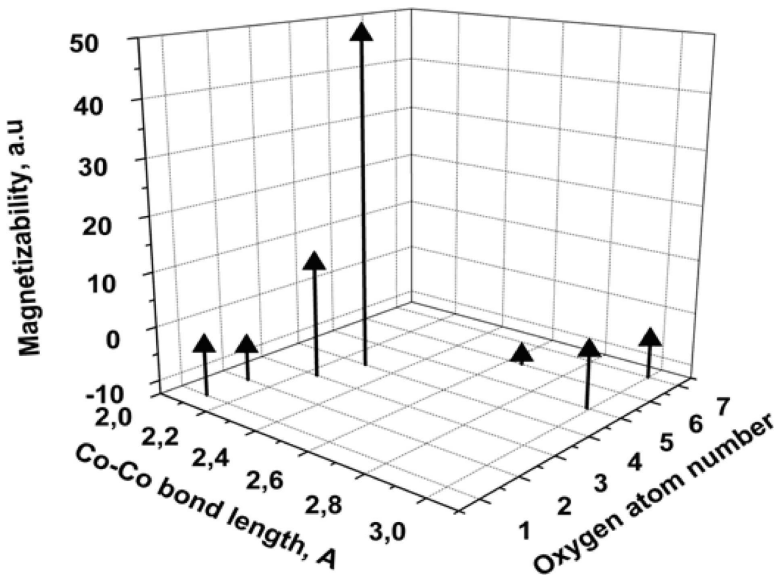

Fig. 4. Magnetizability dependence on Co-Co bond length and oxygen number.

properties of these compounds, because magnetic properties depend on the bond length and nature (Table 1, Fig. 4). Thus, to explain the magnetic properties of the investigated molecules, attention should be paid to the Co-Co bond length, total electron density, and isotropic $g$ tensor that represents the spin angular momentum.

It is possible to see that only $\mathrm{Co}_{2} \mathrm{O}_{3}$ and $\mathrm{Co}_{2} \mathrm{O}_{4}$ are paramagnetic while the other investigated derivatives $\left(\mathrm{Co}_{2} \mathrm{O}, \mathrm{Co}_{2} \mathrm{O}_{2}, \mathrm{Co}_{2} \mathrm{O}_{5}, \mathrm{Co}_{2} \mathrm{O}_{6}\right.$, and $\left.\mathrm{Co}_{2} \mathrm{O}_{7}\right)$ possess diamagnetic properties. Moreover, the magnetizability of $\mathrm{Co}_{2} \mathrm{O}_{4}$ is higher than that of pure Co with magnetizability equal to $14.73 \mathrm{a}$. u. It is notable that the paramagnetic molecule symmetry is higher than in other investigated compounds, but there are not enough cases to make more general conclusions (Table 1).

Firstly, it is necessary to mention that the $\mathrm{Co}-\mathrm{Co}$ bonds are absent in the $\mathrm{Co}_{2} \mathrm{O}_{5}, \mathrm{Co}_{2} \mathrm{O}_{3}$, and $\mathrm{Co}_{2} \mathrm{O}_{7}$ molecules, indicating that the distance between $\mathrm{Co}$ atoms is larger than single bond length, $2.46 \AA[15,16]$. Views of the total electron density confirm the results (Fig. 5(a-g)). It is possible to see that in the case of paramagnetic $\mathrm{Co}_{2} \mathrm{O}_{4}$ the total electron density on $\mathrm{Co}-$ Co bond is smaller than that in the other investigated compound where the bond is present. We predict that in this case the unpaired electron density is present on

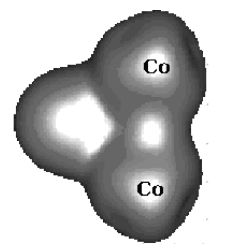

(a)

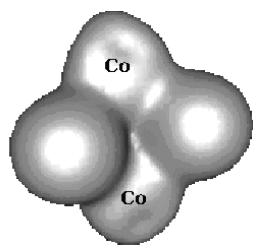

(b)

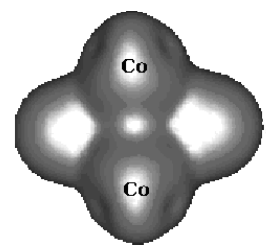

(c)

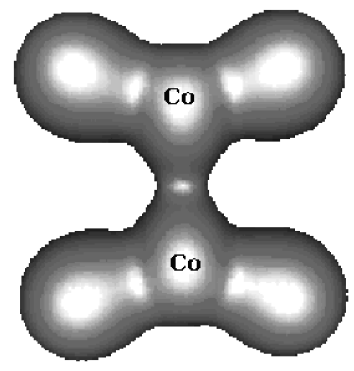

(d)

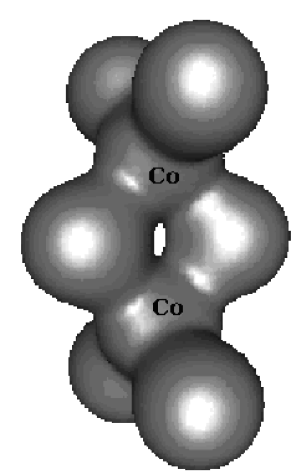

(f)

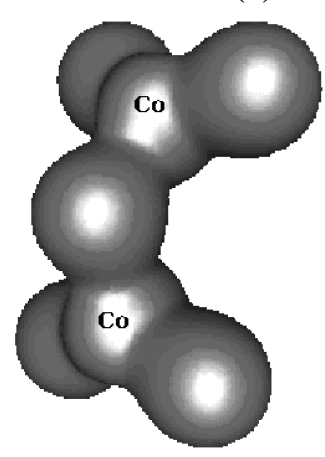

(e)

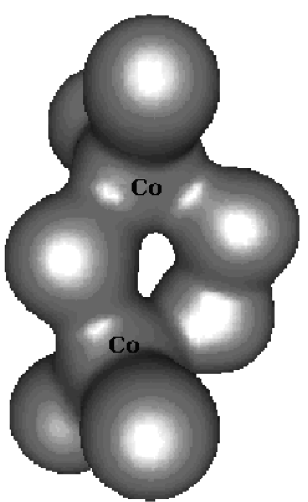

(g)
Fig. 5. Total electron density of the $\mathrm{Co}_{2} \mathrm{O}_{m}(m=1, \ldots, 7)$ particle.

the $\mathrm{Co}-\mathrm{Co}$ bond despite that the system posseses an even number of electrons, i. e. spins are not correlated (compensated), so the paramagnetic properties are observed. The value of the $g$ tensor proves the prediction of unpaired electron spin presence. The absolute value of isotropic $g$ tensor of $\mathrm{Co}_{2} \mathrm{O}_{4}$ is 1.17 - more than half of the free electron $g$ value 2.00. Similar states are obtained in biradicals where the number of atomic orbitals 
that may be occupied is larger than the number of electrons [17]. That leads to appearance of electrons on antibonding orbitals.

Let us remember that the increasing number of $\mathrm{O}$ atoms decreases the difference between the number of electrons and the number of atomic orbitals that they may occupy, so the uncorrelated spins disappear. In our investigated cases, the $\mathrm{Co}_{2} \mathrm{O}_{5}$ and $\mathrm{Co}_{2} \mathrm{O}$ are worse diamagnetics than $\mathrm{Co}_{2} \mathrm{O}_{6}$ and $\mathrm{Co}_{2} \mathrm{O}_{2}$ respectively.

A most interesting situation arises in the case of $\mathrm{Co}_{2} \mathrm{O}_{7}$ and $\mathrm{Co}_{2} \mathrm{O}_{3}$ derivatives. The obtained properties do not correlate with general observations that the increasing number of oxygen atoms leads to uncorrelated spin disappearance and as a consequence the compounds become more diamagnetic. In the above case $\mathrm{Co}_{2} \mathrm{O}_{7}$ is a worse diamagnetic than $\mathrm{Co}_{2} \mathrm{O}_{6}$, while $\mathrm{Co}_{2} \mathrm{O}_{3}$ is paramagnetic. The assumption that in some cases the presence of $\mathrm{O}-\mathrm{O}$ bond influenced the mag- netic properties of $\mathrm{Co}_{2} \mathrm{O}_{3}$ was made. So far we confirm the assumption.

To shed some light on the obtained characteristics we intend to present here the most important orbitals of the paramagnetic compounds (Fig. 6). It is possible to see that adding an oxygen atom to $\mathrm{Co}_{2} \mathrm{O}_{3}$ compounds one makes the unoccupied orbitals the highest occupied molecular orbitals (HOMO-1) of $\mathrm{Co}_{2} \mathrm{O}_{4}$. Additionally, one bonding occupied orbital of $\mathrm{Co}_{2} \mathrm{O}_{3}$ is unoccupied in $\mathrm{Co}_{2} \mathrm{O}_{4}$. Moreover, the additional oxygen atom leads to the partial reversion to the $\mathrm{Co}_{2} \mathrm{O}_{3}$ orbitals, i. e. HOMO of $\mathrm{Co}_{2} \mathrm{O}_{4}$ again becomes LUMO (lowest unoccupied MO) of $\mathrm{Co}_{2} \mathrm{O}_{5}$ (Fig. 6). The energy of the unoccupied orbitals changes dramatically when the oxygen atom number increases from 3 to 4 . Such change leads to the displacement of the two electrons on $\mathrm{d}_{z}^{2}$ orbitals of $\mathrm{Co}$ atoms in the $\mathrm{Co}_{2} \mathrm{O}_{4}$ compound. The above electrons create Co-Co bonds. However, the energy of this orbital is similar to that of the other

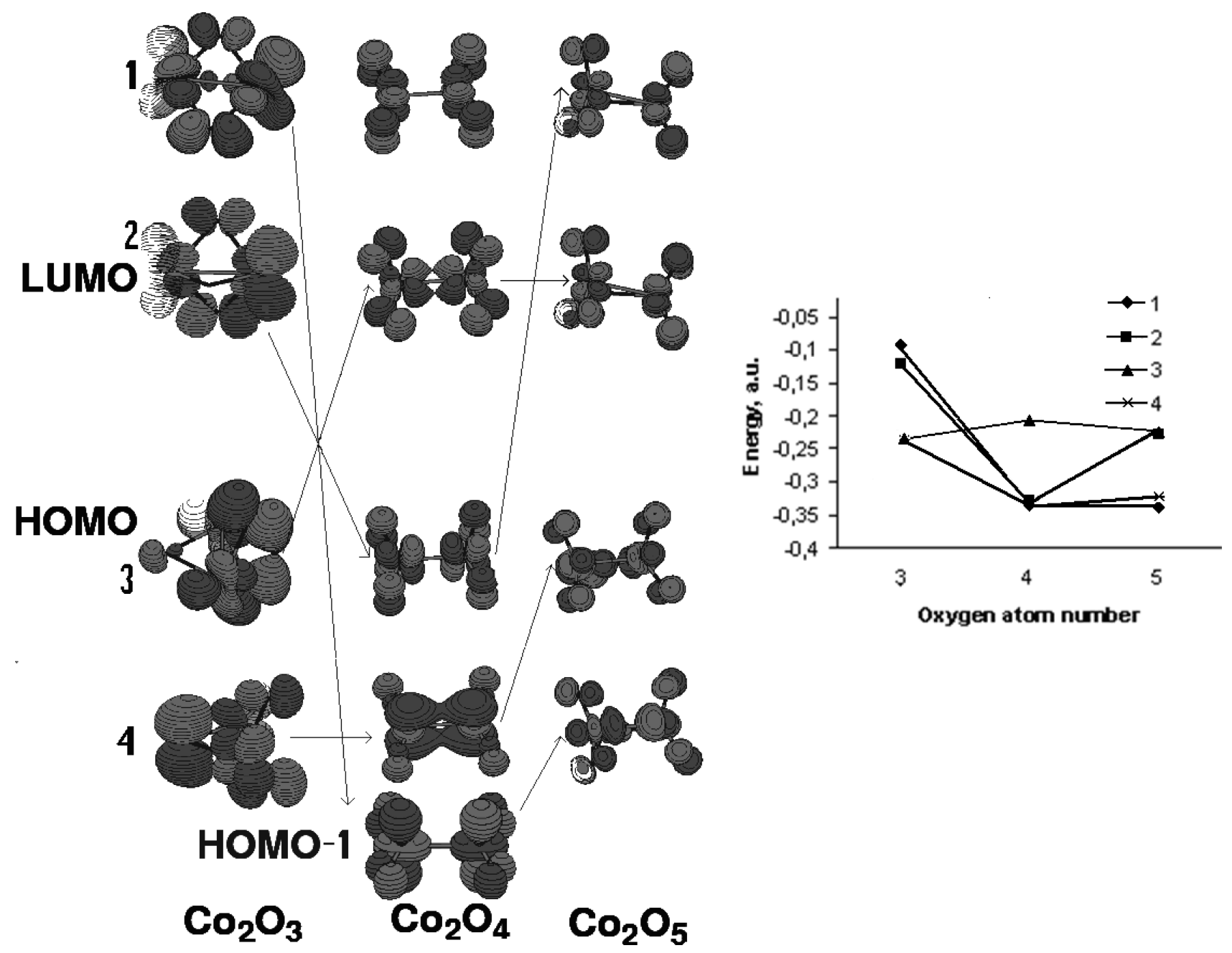

Fig. 6. Correlation diagram of molecular orbitals and their energy dependence on the oxygen atom number. Broad lines in picture represent the structure of the nanoparticles, narrow lines indicate changes of position of molecular function when $\mathrm{O}$ atom number is increasing. Darker structures represent positive parts of atomic functions while grey ones mark the negative parts. 
high-lying antibonding occupied orbital, which are unoccupied in the $\mathrm{Co}_{2} \mathrm{O}_{3}$ compound. Thus, the repulsion between the electrons is larger than in the other investigated compound, therefore they tend to be as far as possible from each other and become non-strongly correlated. The phenomenon observed is the elongation of Co-Co bonds and, as a consequence, the unpaired spin presence. The additional oxygen atom presence leads to smaller electron repulsion and stronger electron correlation because one antibonding orbital becomes unoccupied and its energy decreases (Fig. 6).

Hence, one of the reasons why $\mathrm{Co}_{2} \mathrm{O}_{3}$ is paramagnetic is the lower electron density on the $\mathrm{Co}-\mathrm{Co}$ bond than in $\mathrm{Co}_{2} \mathrm{O}_{4}$ (Fig. 5(d)). However, the presence of Co-Co bonds does not explain fully why the absolute values of isotropic $g$ tensor of the above compound is equal to 0.58 , being much more smaller than that of $\mathrm{Co}_{2} \mathrm{O}_{4}$ and slightly larger than that of the other investigated molecules (Table 1). In addition, it has been pointed out that an orbital shift is obtained when $\mathrm{Co}_{2} \mathrm{O}_{2}$ compound accepts an additional oxygen atom (that is the reason why the results are not presented). On the other hand, most probably the charge density between Co-Co bonds appears due to overlap of p orbital of oxygen atoms (Fig. 6). It implies that the paramagnetic properties of the $\mathrm{Co}_{2} \mathrm{O}_{3}$ are related with electrons occupying the $\mathrm{p}$ orbitals of different oxygen atoms. That leads to the formation of a biradical due to charge location on certain atoms and, as a consequence, to the appearance of repulsion electrons due to steric hindrance. Meanwhile, only $\mathrm{Co}_{2} \mathrm{O}_{7}$ derivative possesses $\mathrm{O}-\mathrm{O}$ bonds and their diamagnetic properties are worse than those of $\mathrm{Co}_{2} \mathrm{O}_{7}$. Obviously, the prediction that the presence of $\mathrm{O}-\mathrm{O}$ bond may decrease diamagnetic properties is confirmed.

In summary, it is possible to foresee that the Co compound will be paramagnetic due to several reasons: (i) the unpaired electron location on the $\mathrm{Co}-\mathrm{Co}$ bonds, (ii) the small total electron charge density between Co atoms which appears due to overlap of $p$ orbitals of the oxygen atoms.

\section{Conclusion}

In the effort to shed light on the stability and magnetic properties of the $\mathrm{Co}_{2} \mathrm{O}_{n}$ derivatives the quantum mechanical investigations were performed. We obtained that the most stable NP is $\mathrm{Co}_{2} \mathrm{O}_{6}$, while only the stability of $\mathrm{Co}_{3} \mathrm{O}_{4}$ and $\mathrm{CoO}$ has been reported earlier. Investigation of magnetization indicates that the compound with high symmetry is demonstrating paramagnetic features. Calculation results show that only $\mathrm{Co}_{2} \mathrm{O}_{3}$ and $\mathrm{Co}_{2} \mathrm{O}_{4}$ display paramagnetic properties while other investigated derivatives $\left(\mathrm{Co}_{2} \mathrm{O}, \mathrm{Co}_{2} \mathrm{O}_{2}\right.$, and $\mathrm{Co}_{2} \mathrm{O}_{6}$ ) reveal diamagnetic properties. Investigation of the most important orbitals and total electron density distribution allows us to foresee that the Co compound will be paramagnetic.

\section{Acknowledgements}

Support from EU project PHOREMOST (N 511616), EU project HPC-EUROPA (RII3-CT-2003-506079), CICYT of Spain (CTQ2006-15611-CO2-01), project FP6-2004-Infrastructures-6 (contract No. 026715) "BalticGrid", projects "LitGrid" and "GridTechno" are gratefully acknowledged. The work is partly supported by COST P19 activity.

\section{References}

[1] D.A. Resnick, K. Gilmore, Y.U. Idzerda, M.T. Klem, M. Allen, T.T. Douglas, E. Arenholz, and M. Young, Magnetic properties of $\mathrm{Co}_{3} \mathrm{O}_{4}$ nanoparticles mineralized in Listeria innocua Dps, J. Appl. Phys. 99, 08Q501 (2006).

[2] M. Sakurai, K. Watanabe, K. Sumiyama, and K. Suzuki, Magic numbers in Fe clusters produced by laser vaporization source, J. Phys. Soc. Jpn. 67, 2571 (1998).

[3] P. Gambardella, S. Rusponi, M. Veronese, S.S. Dhesi, C. Grazioli, A. Dallmeyer, I. Cabria, R. Zeller, P.H. Dederichs, K. Kern, C. Carbone, and H. Brune, Giant magnetic anisotropy of single cobalt atoms and nanoparticles, Science 300, 1130 (2003).

[4] J. Nogués, V. Skumryev, J. Sort, S. Stoyanov, and D. Givord, Shell-driven magnetic stability in core-shell nanoparticles, Phys. Rev. Lett. 97, 157203 (2006).

[5] Sh. Tsukamoto and N. Koguchi, Magic numbers in Ga clusters on GaAs ( $\left.\begin{array}{lll}0 & 0 & 1\end{array}\right)$ surface, J. Crystal Growth 209, 258 (2000).

[6] M. Ghosh, E.V. Sampathkumaran, and C.N.R. Rao, Synthesis and magnetic properties of $\mathrm{CoO}$ nanoparticles, Chem. Mater. 17, 2348 (2005).

[7] A.D. Becke, Density-functional thermochemistry. III. The role of exact exchange, J. Chem. Phys. 98, 5648 (1993).

[8] M.S. Gordon, J.S. Binkley, J.A. Pople, W.J. Pietro, and W.J. Hehre, Self-consistent molecular-orbital methods. 22. Small split-valence basis sets for second-row elements, J. Am. Chem. Soc. 104, 2797 (1982). 
[9] M.W. Schmidt, K.K. Baldrige, J.A. Boatz, S.T. Elbert, M.S. Gordon, J.H. Jensen, S. Koseki, N. Matsunaga, K.A. Nguyen, Shujun Su, T.L. Windus, M. Dupuis, and J.A. Montgomery Jr., General atomic and molecular electronic structure system, J. Comput. Chem. 14, 1347 (1993).

[10] Gaussian 03, Revision C.02, M.J. Frisch, G.W. Trucks, H.B. Schlegel, G.E. Scuseria, M.A. Robb, J.R. Cheeseman, J.A. Montgomery Jr., T. Vreven, K.N. Kudin, J.C. Burant, J.M. Millam, S.S. Iyengar, J. Tomasi, V. Barone, B. Mennucci, M. Cossi, G. Scalmani, N. Rega, G.A. Petersson, H. Nakatsuji, M. Hada, M. Ehara, K. Toyota, R. Fukuda, J. Hasegawa, M. Ishida, T. Nakajima, Y. Honda, O. Kitao, H. Nakai, M. Klene, X. Li, J.E. Knox, H.P. Hratchian, J.B. Cross, V. Bakken, C. Adamo, J. Jaramillo, R. Gomperts, R.E. Stratmann, O. Yazyev, A.J. Austin, R. Cammi, C. Pomelli, J.W. Ochterski, P.Y. Ayala, K. Morokuma, G.A. Voth, P. Salvador, J.J. Dannenberg, V.G. Zakrzewski, S. Dapprich, A.D. Daniels, M.C. Strain, O. Farkas, D.K. Malick, A.D. Rabuck, K. Raghavachari, J.B. Foresman, J.V. Ortiz, Q. Cui, A.G. Baboul, S. Clifford, J. Cioslowski, B.B. Stefanov, G. Liu, A. Liashenko, P. Piskorz, I. Komaromi, R.L. Martin, D.J. Fox, T. Keith, M.A. Al-Laham, C.Y. Peng, A. Nanayakkara, M. Challacombe, P.M.W. Gill, B. Johnson, W. Chen, M.W. Wong, C. Gonzalez, and J.A. Pople, Gaussian, Inc., Wallingford CT (2004).
[11] DALTON, a molecular electronic structure program, Release 2.0 (2005), see http://www.kjemi.uio.no/ software/dalton/dalton.html .

[12] A. Schafer, H. Horn, and R. Ahlrichs, Fully optimized contracted Gaussian basis sets for atoms $\mathrm{Li}$ to $\mathrm{Kr}$, J. Chem. Phys. 97, 2571 (1992).

[13] P.-O. Astrand, K.V. Mikkelsen, K. Ruud, and T. Helgaker, Magnetizabilities and nuclear shielding constants of the fluoromethanes in the gas phase and solution, J. Phys. Chem. 100, 19771 (1996).

[14] J. Tamulienė, R. Vaišnoras, M.-L. Balevičius, and L. Rastinienè, Geometrical structure of small Co nanoparticles, in: Advanced Optical Materials, Technologies, and Devices, eds. S. Ašmontas and J. Gradauskas, Proc. SPIE 6596, 65961G (2006).

[15] Tables of Interatomic Distances and Configuration in Molecules and Ions, Supplement 1956-1959, ed. L.E. Sutton, Special publication No. 18 (Chemical Society, London, UK, 1965).

[16] L. Pauling, Evidence from bond lenghts and bond angles for enneacovalence of cobalt, rhodium, iridium, iron, ruthenium, and osmium in compounds with elements of medium electronegativity, Proc. Natl. Acad. Sci. USA 81, 1918 (1984).

[17] A. Shimizu, M. Uruichi, K. Yakushi, M. Nakano, D. Shiomi, T. Kubo, T. Takui, Y. Morita, and K. Nakasuji, Singlet biradical character of phenalenyl-based Kekulé hydrocarbon with naphthoquinoid structure, Org. Lett. 9, 81 (2007).

\title{
$\mathrm{Co}_{2} \mathrm{O}_{m}(m=1, \ldots, 7)$ KLASTERIŲ STABILUMAS IR MAGNETINĖS SAVYBĖS
}

\author{
J. Tamulienè ${ }^{\mathrm{a}}$, R. Vaišnoras ${ }^{\mathrm{b}}$, G. Badenes $^{\mathrm{c}}$, L.M. Balevičius ${ }^{\mathrm{d}}$ \\ ${ }^{a}$ Vilniaus universiteto Teorinès fizikos ir astronomijos institutas, Vilnius, Lietuva \\ ${ }^{\mathrm{b}}$ Vilniaus pedagoginis universitetas, Vilnius, Lietuva \\ ${ }^{\mathrm{c}}$ Fotoniniu mokslu institutas, Castelldefels, Ispanija \\ ${ }^{\mathrm{d}}$ Vilniaus universiteto Fizikos fakultetas, Vilnius, Lietuva
}

\begin{abstract}
Santrauka
Pateikti $\mathrm{Co}_{2} \mathrm{O}_{m}(m=1, \ldots, 7)$ daleliu kvantinès chemijos tyrimai atlikti tankio funkcionalo metodu (B3LYP) 6-31G bazès artinyje. Nustatyta, $\mathrm{kad} \mathrm{Co}_{2} \mathrm{O}_{6}$ dalelès yra stabiliausios tarp visų tirtu darinių, todèl tikètina, kad jos turi būti aptinkamos greta $\mathrm{Co}_{3} \mathrm{O}_{4}$ ir $\mathrm{CoO}$ dalelių, kurių savybès yra plačiai aprašytos. İvertinus dalelių magnetinamumą ir izotropinio $g$ tenzoriaus vertę nustatyta, kad tik $\mathrm{Co}_{2} \mathrm{O}_{3}$ ir $\mathrm{Co}_{2} \mathrm{O}_{4}$ yra paramagnetikai, o visos kitos tirtos dalelès - diamagnetikai. Pastebèta, kad paramagnetinių dalelių taškinių
\end{abstract}

grupių simetrija yra aukštesnè nei diamagnetinių, tačiau šiuo metu turimų tyrimų rezultatų nepakanka, kad šis pastebejjimas būtu pateiktas kaip išvada. Remiantis rezultatais, kurie gauti išanalizavus paramagnetinių junginių aukščiausių užimtu (HOMO) ir žemiausių neužimtu (LUMO) orbitalių ir elektronų tankị, nustatyta, kad tirti dariniai gali būti paramagnetikai dẻl keliu priežasčių: 1) dèl nesuporuotų sukinių elektronų išsidèstymo ant Co-Co jungties, 2) dèl nedidelio elektronu tankio tarp Co atomų, atsirandančio persiklojant deguonies atomų p orbitalėms. 